\title{
Intercropping of Roselle with Red Gram and Nipped Castor is Beneficial to Dry Land Farmer
}

\author{
T.N. Pushpa ${ }^{\text {* }}$, K. Umesha ${ }^{2}$, M. Vasundhara ${ }^{3}$, B.K. Ramachandrappa ${ }^{4}$, \\ B.S. Sreeramu ${ }^{3}$ and D. Srikantaprasad ${ }^{1}$ \\ ${ }^{1}$ Department of PSMA, KRCCH, Arabhavi, Gokak Tq. Belagavi Dist. Karnataka 591218, India \\ ${ }^{2}$ Department of PSMA, College of Horticulture (UHS) Bengaluru, Karnataka 560065, India \\ ${ }^{3}$ Division of Horticulture, College of Agriculture, UAS, GKVK, Bengaluru, \\ Karnataka 560065, India \\ ${ }^{4}$ AICRP on Dryland Agriculture, UAS, GKVK, Bengaluru, Karnataka 560065, India \\ *Corresponding author
}

A B S T R A C T

\begin{tabular}{|c|}
\hline Keywords \\
\hline $\begin{array}{l}\text { Roselle, Holy basil, } \\
\text { Garden rue, } \\
\text { Ashwagandha, } \\
\text { LER, ATER. }\end{array}$ \\
\hline Article Info \\
\hline $\begin{array}{l}\text { Accepted: } \\
23 \text { August } 2017 \\
\text { Available Online: } \\
\text { 10 September } 2017\end{array}$ \\
\hline
\end{tabular}

This study was conducted on intercropping of medicinal crops viz., ashwagandha, garden rue, roselle and holy basil with pigeon pea and nipped castor in alfisols of eastern dry zone of Karnataka in kharif 2011. The growth and yield of pigeon pea and castor were high in sole crop than all intercropping systems. The growth and yield of ashwagandha, roselle and holy basils were reduced under intercropping systems. The highest fresh calyces yield of roselle was recorded in sole crop (6.75 $\left.\mathrm{t} \mathrm{ha}^{-1}\right)$ followed by pigeon pea + roselle $\left(4.06 \mathrm{t} \mathrm{ha}^{-1}\right)$ and lowest in castor + roselle $\left(3.39 \mathrm{t} \mathrm{ha}^{-1}\right)$. The yield of holy basil in pigeon pea + holy basil intercropping (1.75 $\left.\mathrm{t} \mathrm{ha}^{-1}\right)$ was at par with castor + holy basil $\left(0.81 \mathrm{tha}^{-1}\right)$ intercropping system. The pigeon pea + roselle intercropping system recorded significantly highest LER, ATER and net returns (1.41, 1.35 and $76012.00 \mathrm{ha}^{-1}$, respectively) followed by castor + roselle $\left(1.29,1.29\right.$ and $` 62944.00 \mathrm{ha}^{-1}$, respectively).

\section{Introduction}

Ever increasing human and livestock population need additional food which has to come from the dry land farming only. But, the system is characterized by erratic rainfall and crop failure due to droughts during critical stages. With an estimated annual turn-over of the herbal industry in the country to a tune of ₹ 8800 crores (Ved and Goraya, 2008), besides the staple food crops, medicinal crops are also important for mankind. They constitute 30 per cent of the allopathic drugs and a major part of many traditional medical systems. Systematic cultivation of medicinal crops as pure crops is not encouraging as they may associate with unattractive benefit, long gestation period, large fluctuation in production potential and discouraging government policies (Prakasa Rao, 1996). Under these circumstances, the only option open is through time and space utilization in rainfed agriculture systems (Sankaran and Rangaswamy, 1990) by adopting 
intercropping systems. As a step forward in this direction, a study on intercropping of medicinal crops in alfisols of dry land conditions in Eastern Dry zone of Karnataka was carried out to integrate the medicinal crops (garden rue, ashwagandha, roselle and holy basil) as intercrops with pigeon pea and castor.

\section{Materials and Methods}

The field experiment was carried out at the Post Graduate Center, University of Horticultural Sciences (Bagalkot), Gandhi Krishi Vignana Kendra, Bengaluru, during kharif 2011. The experimental site is situated in Eastern Dry Zone of Karnataka at $12^{0} 51^{\text {' }}$ North and $77^{\circ} 35^{\prime}$ East with an altitude of 930 $\mathrm{m}$ above MSL. The soil was red sandy loam with acidic $\mathrm{pH}$ (5.11), medium EC (0.086 $\left.\mathrm{dSm}^{-1}\right)$, low organic carbon $(0.45 \%)$ and available $\mathrm{P}_{2} \mathrm{O}_{5}\left(29.37 \mathrm{~kg} \mathrm{ha}^{-1}\right)$, and medium in available $\mathrm{N}$ and $\mathrm{K}_{2} \mathrm{O}\left(297.92\right.$ and $163 \mathrm{~kg} \mathrm{ha}^{-1}$, respectively) and grouped under Alfisols. The highest monthly rainfall in 2011 was received in August (253.2 mm, 17 rainy days) and the lowest was in June (30.0 mm, 5 rainy days). During the cropping season (May November), a total of $725.3 \mathrm{~mm}$ rainfall was received. There was a short dry spell observed during the germination stage and intermittent dry spells during early reproductive and maturity stage of pigeon pea and castor. Hence, two lifesaving irrigations were given to ensure uniform germination of seeds.

The experiment comprised of 4 medicinal plants viz., garden rue (Ruta graveolens L.), ashwagandha (Withania somnifera Dunal. cv. Poshita), roselle (Hibiscus sabdariffa L. var. sabdariffa) and purple type of holy basil (Ocimum sanctum L.) and two field crops viz., pigeon pea (Cajanus cajan (L.) Millsp. cv. BRG-1) and nipped castor (Ricinus communis cv. DCH-9) laid out in Randomized Complete Block Design (RCBD) with three replications with a gross plot size of 28.8 sq. m.

The treatments consisted of six sole crops, four intercropping combinations of medicinal crops with each of red gram and castor. Three rows of ashwagandha, two rows of garden rue and holy basil and one row of roselle were grown as intercrops in between two rows of pigeon pea and castor which was spaced $120 \mathrm{~cm}$ apart. The seed rate for sole crop of garden rue, ashwagandha, roselle and holy basil was 2-2.5, 5.00, 2-3 and 0.2-0.3 $\mathrm{kg} \mathrm{ha}^{-1}$. While, it was $12 \mathrm{~kg} \mathrm{ha}^{-1}$ for both red gram and castor. Whereas 40:40:40, 0:0:0, 90: 60:40, 120:105:105, 25:50:25 + Zinc-15 + Sulphur-20 and $38: 38: 25 \mathrm{kgs}$ of $\mathrm{N}, \mathrm{P}_{2} \mathrm{O}_{5}$ and $\mathrm{K}_{2} \mathrm{O}$ were applied to garden rue, ashwagandha, roselle, holy basil, pigeon pea and castor respectively.

The land was ploughed twice, clods were crushed and brought to fine tilth by passing harrow. Irrespective of crops, farm yard manure was applied to each plot at the rate of 10 tons $\mathrm{ha}^{-1}$ a month before final levelling and mixed thoroughly. Fifty per cent of nitrogen and entire dose of $\mathrm{P}$ and $\mathrm{K}$ were applied as basal dose at the time of sowing. The remaining fifty per cent of nitrogen was given as top dressing during earthing up at thirty day after sowing. Bold and healthy seeds of pigeon pea, castor, ashwagandha and roselle were soaked in water over night. Pigeon pea seeds were treated with Rizobium and Trichoderma harzianum, while, castor, ashwagandha and roselle seeds were treated with Captan@2g per kg. Pigeon pea, castor and roselle seeds were dibbled at $0.5 \mathrm{~cm}$ depth and the seeds of ashwagandha sown in shallow furrows and the rows were covered with soil in the second week of June. The garden rue and holy basil seedlings were raised in nursery for a month and transplanted to the experimental plots during second week of July. The gap filling was done after eight 
days of sowing/transplanting and the plots were kept weed free throughout the experimentation.

Castor was nipped at the height of first spike initiation and initiated spike was removed and a vertical branch was allowed to grow from the node below the first spike. Finally four spikes were maintained per plant. The inflorescence was nipped off in holy basil for initial two months of planting to ensure maximum branching and more vegetative growth. Observations were recorded from five randomly tagged plants in each plot. The growth parameters like plant height $(\mathrm{cm})$, plant spread $(\mathrm{cm})$, number of branches per plant, number of leaves per plant, leaf area at harvest (sq. $\mathrm{cm}$ ) and dry weight of different plant components $\left(\mathrm{g}\right.$ plant $\left.^{-1}\right)$ and different yield parameters were recorded according to the crop. The major chemical constituents of medicinal plants such as anthocyanin in roselle calyces and eugenol in essential oil of holy basil were determined.

The essential oil of shade dried holy basil herb was obtained using Clevenger's apparatus and expressed in percentage on shade dry weight basis. Gas Chromatography analysis was carried out to estimate the eugenol in holy basil essential oil by employing Varian 450GC fitted with Auto injector, CPSil8 column $(250 \mathrm{~mm} \times 4.6 \mathrm{~mm})$ and FID detector. Nitrogen was used as mobile phase and makeup gas. The injector port was heated and held at $250^{\circ} \mathrm{C}$, the column temperature was initially held at $40^{\circ} \mathrm{C}$ for three minutes, then heated to $228^{\circ} \mathrm{C}$ at a rate of $4^{\circ} \mathrm{C}$ per minute and finally held at this temperature for two minutes. The flow rate was set to $1 \mathrm{ml}$ per minute with a run time of 52 minutes, while the spilt ratio was 1:36 and the ionization was detected at $280^{\circ} \mathrm{C}$. Pure eugenol (98.3\%) obtained from M/S Natural Remedies India, Pvt. Ltd. Co. Bengaluru was used as the reference compound.
Calyces were extracted with ethanol (95\%) and $1.5 \mathrm{~N} \mathrm{HCl}$ in the ratio of 85:15. The extract was transferred to $100 \mathrm{ml}$ volumetric flask, made up the volume and stored in the refrigerator overnight at $4^{\circ} \mathrm{C}$, and then filtered through Whatman no. 1 filter paper and the optical density (OD) was measured at $535 \mathrm{~nm}$ using spectrophotometer. The anthocyanin content was calculated and expressed as $\mathrm{mg}$ per $100 \mathrm{~g}$ fresh weight of calyces.

Land equivalent ratio (Willey, 1979) and area time equivalent ratio (Hiebsch, 1980) were calculated. The economic analysis was done by considering the market price prevailed during 2011-12.

\section{Result and Discussion}

\section{Effect of intercropping systems on growth and yield parameters of pigeon pea}

The higher values for growth and yield parameters like, plant height $(165.1 \mathrm{~cm})$, plant spread $(95.0 \mathrm{~cm})$, Number of branches per plant (14.0), maximum leaf area (4608 sq. cm plant $\left.^{-1}\right)$, dry weight of leaves $(21.60 \mathrm{~g})$, maximum number of pods (207) and seed yield (127.87 $\mathrm{g}$ plant $^{-1}$ and $23.10 \mathrm{q} \mathrm{ha}^{-1}$ ) were recorded by sole crop of pigeon pea (Table 1). While, the pigeon pea + ashwagandha intercropping system recorded least values for all these characters and the values were not comparable with a normal crop. Since there was no space to collect the soil and to raise along the pigeon pea row when ashwagandha was grown as intercrop, it was deprived of the advantages of earthing up. Similarly, higher yields from sole crop of pigeon pea than in intercropping systems are reported by Koppalkar (2007) when ashwagandha was incorporated with various row proportions.

Roselle offered greater competition to the pigeon pea due to its robust branches with broader leaves. Since the early uptake of 
nutrients seems to be the key to success in competition for mobile nutrients such as nitrogen and potassium (Kawano et al., 1974). The growth of pigeon pea was reduced when grown with roselle. Roselle might also have competed with pigeon pea for nutrients as recommended dose of fertilizer was applied only to pigeon pea and not for roselle. Both the crops are deep rooted dry land crops and there might have been a stiff competition for nutrients.

Due to very poor growth of garden rue, there was no competition in pigeon pea + garden rue intercropping system, and it recorded yield comparable with that of sole crop of pigeon pea.

\section{Effect of intercropping systems on growth and yield parameters of castor}

Similar to pigeon pea, castor also recorded lower values for growth parameters when grown along with ashwagandha. The lowest leaf area was recorded in castor + roselle (1580 sq. cm plant ${ }^{-1}$ ) intercropping system (Table 2). Since castor with roselle recorded significantly less plant spread $(82.7 \mathrm{~cm})$ as a result of competition between crops, it had lesser leaf area. Whereas, there was no or less intercrop competition in sole crop of castor, castor + holy basil and castor + garden rue intercropping systems and the leaf area of castor remain unchanged (these systems were on par). The trend was more or less same with respect to dry weight of leaves.

The length of spike remained unchanged due to intercropping with garden rue and holy basil, while, the spike length varied significantly due to intercropping with ashwagandha and roselle (Table 2). But, the number of capsules per spike differed significantly even with intercropping of garden rue (33) as compared to sole crop of castor (37). Since, the previously discussed growth parameters were found to be better in sole crop of castor, castor + holy basil and castor + garden rue intercropping systems, the yield parameters were also found better as compared to other treatments. The yield was found to be high in sole crop of castor which did not vary with other intercropping system, except ashwagandha, since the growth and yield attributes like plant height, plant spread, number of leaves, leaf area; dry weight of leaf, spike length and number of capsule were found to be high in these intercropping systems. While, the yield was reduced to a greater extent in castor + ashwagandha intercropping system, as it was found to reduce various growth and yield attributing parameters. From a similar study, Prasad and Verma (1986) reported that seed yield of castor was unaffected when green gram and black gram were intercropped with it, while, sesamum and sorghum reduced the yield. When castor was intercropped with maize, the yield reduction was 46.26 per cent (Gupta and Rathore, 1993) due to mutual competition.

\section{Effect of intercropping systems on growth and yield parameters of garden rue}

The garden rue crop failed to establish in the experimental plots as the bare rooted seedlings were transplanted to main field. This may be due to transplanting shock. Therefore, no data were recorded.

\section{Effect of intercropping systems on growth, yield and quality parameters of ashwagandha}

The effect of intercropping on plant height and number of branches was not significant at all the growth stages. While, the plant spread was influenced by intercropping system only at harvest. Due to shading effect of pigeon pea and castor and resulted in lanky growth, but higher in sole crop of ashwagandha (Table 3). 
Table.1 Effect of intercropping systems on growth and yield parameters of pigeon pea

\begin{tabular}{|c|c|c|c|c|c|c|c|c|}
\hline Treatments & $\begin{array}{l}\text { Plant height at } \\
\text { harvest }(\mathbf{c m})\end{array}$ & $\begin{array}{c}\text { Plant spread at } \\
\text { harvest }(\mathrm{cm})\end{array}$ & $\begin{array}{c}\text { Number of } \\
\text { branches per } \\
\text { plant at harvest }\end{array}$ & $\begin{array}{c}\text { Leaf area } \\
\left(\mathrm{sq} \cdot \mathrm{cm}^{-1}\right. \\
\left.\text { plant }^{-1}\right)\end{array}$ & $\begin{array}{c}\text { Dry weight } \\
\text { of leaves ( } g \\
\left.\text { plant }^{-1}\right)\end{array}$ & $\begin{array}{l}\text { Number of } \\
\text { pods plant } \\
1\end{array}$ & $\begin{array}{c}\text { Seed } \\
\text { yield } \\
\left(\text { g plant }^{-1}\right)\end{array}$ & $\begin{array}{c}\text { Seed } \\
\text { yield } \\
\left(\mathbf{q ~ h a} \mathbf{~}^{-1}\right)\end{array}$ \\
\hline $\mathrm{T}_{5-}$ Sole Pigeon pea & 165.1 & 95.0 & 14.0 & 4608 & 21.60 & 207 & 127.87 & 23.10 \\
\hline $\mathrm{T}_{7 \text { - }}$ Pigeon pea + Garden rue & 160.3 & 89.5 & 12.3 & 3987 & 17.08 & 188 & 111.20 & 19.75 \\
\hline $\mathrm{T}_{8 \text { - }}$ Pigeon pea + Ashwagandha & 151.9 & 83.4 & 11.8 & 3564 & 16.24 & 140 & 91.80 & 16.22 \\
\hline T 9. Pigeon pea + Roselle & 160.7 & 81.7 & 11.5 & 3588 & 17.03 & 147 & 101.00 & 18.27 \\
\hline $\mathrm{T}_{10-}$ Pigeon pea + Holy basil & 162.9 & 89.6 & 13.7 & 4578 & 18.67 & 204 & 122.40 & 19.06 \\
\hline S.Em \pm & 2.4 & 2.2 & 0.8 & 167 & 0.53 & 13 & 6.91 & 1.17 \\
\hline C.D. at $5 \%$ & $9.4^{*}$ & $7.2^{*}$ & $\mathrm{NS}$ & $546 *$ & $1.74 *$ & $37 *$ & $22.54 *$ & $3.84 *$ \\
\hline
\end{tabular}

*:- Significant, NS: - Non significant

Table.2 Effect of intercropping systems on growth and yield parameters of castor

\begin{tabular}{|c|c|c|c|c|c|c|c|c|c|c|c|}
\hline Treatments & $\begin{array}{c}\text { Plant } \\
\text { height } \\
(\mathrm{cm}) \mathrm{At} \\
\text { harvest }\end{array}$ & $\begin{array}{c}\text { Plant } \\
\text { spread } \\
(\text { cm)At } \\
\text { harvest }\end{array}$ & $\begin{array}{c}\text { Number } \\
\text { of leaves } \\
\text { per plant } \\
\text { At } \\
\text { harvest }\end{array}$ & $\begin{array}{c}\begin{array}{c}\text { Leaf } \\
\text { area }\end{array} \\
(\text { sq. cm } \\
\left.\text { plant }^{-1}\right)\end{array}$ & $\begin{array}{c}\text { Dry } \\
\text { weight of } \\
\text { leaves } \\
\left(\text { g plant }^{-1}\right)\end{array}$ & $\begin{array}{c}\text { Number } \\
\text { of spikes } \\
\text { plant }^{-1}\end{array}$ & $\begin{array}{l}\text { Length of } \\
\text { spike } \\
(\mathrm{cm})\end{array}$ & $\begin{array}{l}\text { Number of } \\
\text { capsules } \\
\text { spike }^{-1}\end{array}$ & $\begin{array}{c}100 \text { seed } \\
\text { weight } \\
\left(\text { g plant }^{-1}\right)\end{array}$ & $\begin{array}{l}\text { Seed yield } \\
\left(\text { g plant }^{-1}\right)\end{array}$ & $\begin{array}{l}\text { Seed } \\
\text { yield } \\
\left(\mathbf{q} \mathbf{h a}^{-1}\right)\end{array}$ \\
\hline $\mathrm{T}_{6-}$ Sole Castor & 155.3 & 96.3 & 10 & 2642 & 6.27 & 4 & 37.1 & 37 & 22.13 & 106.87 & 20.59 \\
\hline $\mathrm{T}_{11-}$ Castor + Garden rue & 154.3 & 92.0 & 10 & 2013 & 4.85 & 3 & 37.9 & 33 & 21.80 & 96.87 & 18.94 \\
\hline $\mathrm{T}_{12-}$ Castor + Ashwagandha & 127.2 & 90.0 & 10 & 1649 & 3.82 & 3 & 30.7 & 33 & 22.20 & 86.27 & 15.71 \\
\hline $\mathrm{T}_{13-}$ Castor +Roselle & 151.5 & 82.7 & 9 & 1580 & 3.90 & 3 & 31.1 & 30 & 22.80 & 89.13 & 18.02 \\
\hline $\mathrm{T}_{14-}$ Castor + Holy basil & 157.3 & 93.9 & 10 & 2600 & 6.25 & 4 & 34.0 & 36 & 22.60 & 99.40 & 19.04 \\
\hline S.Em \pm & 3.5 & 2.6 & 0.5 & 219 & 0.50 & 0.17 & 1.67 & 1.13 & 0.27 & 3.13 & 0.88 \\
\hline C.D. at $5 \%$ & $13.9^{*}$ & $8.3^{*}$ & NS & $713^{*}$ & $1.63^{*}$ & NS & $5.4^{*}$ & $4^{*}$ & NS & $10.22 *$ & $2.87^{*}$ \\
\hline
\end{tabular}

*:- Significant, NS: - Non significant 
Table.3 Effect of intercropping systems on growth, yield and quality parameters of ashwagandha

\begin{tabular}{|c|c|c|c|c|c|c|c|c|c|c|}
\hline Treatments & $\begin{array}{c}\text { Plant height } \\
\text { at harvest } \\
(\mathrm{cm})\end{array}$ & $\begin{array}{c}\text { Plant } \\
\text { spread at } \\
\text { harvest }(\mathbf{c m})\end{array}$ & $\begin{array}{c}\begin{array}{c}\text { Number of } \\
\text { branches plant } \\
{ }^{-} \text {at harvest }\end{array} \\
\end{array}$ & $\begin{array}{c}\text { Number of } \\
\text { primary } \\
\text { roots }\end{array}$ & $\begin{array}{l}\text { Length of } \\
\text { roots }(\mathrm{cm})\end{array}$ & $\begin{array}{l}\text { Thickness of } \\
\text { roots (mm) }\end{array}$ & $\begin{array}{l}\text { Plant dry } \\
\text { weight (g) }\end{array}$ & $\begin{array}{c}\text { Dry weight of } \\
\text { roots } \\
\left(\mathrm{g} \mathrm{plant}^{-1}\right)\end{array}$ & $\begin{array}{c}\text { Root yield } \\
\left(\mathrm{kg} \mathrm{ha}^{-1}\right)\end{array}$ & Grade \\
\hline $\mathrm{T}_{2-}$ Sole Ashwagandha & 33.8 & 17.8 & 3.9 & 3.93 & 10.8 & 6.8 & 4.71 & 0.57 & 29.91 & $\mathrm{~B}$ \\
\hline $\mathrm{T}_{8-}$ Pigeon pea + Ashwagandha & 30.1 & 16.1 & 3.1 & 2.27 & 7.9 & 5.1 & 2.39 & 0.33 & 13.89 & $\mathrm{~B}$ \\
\hline $\mathrm{T}_{12-}$ Castor + Ashwagandha & 33.4 & 11.9 & 2.7 & 2.47 & 8.9 & 6.7 & 1.85 & 0.41 & 9.07 & $\mathrm{~B}$ \\
\hline S.Em \pm & 3.30 & 1.16 & 0.3 & 0.62 & 0.7 & 0.42 & 0.58 & 0.04 & 4.04 & - \\
\hline C.D. at $5 \%$ & NS & $4.54 *$ & NS & NS & NS & NS & $2.26^{*}$ & $0.15^{*}$ & $15.85^{*}$ & - \\
\hline
\end{tabular}

*:- Significant, NS: - Non significant

Table.4 Effect of intercropping systems on growth, yield and quality parameters of roselle

\begin{tabular}{|c|c|c|c|c|c|c|c|c|c|c|c|c|c|c|}
\hline Treatments & $\begin{array}{c}\text { Plant } \\
\text { height at } \\
\text { harvest } \\
(\mathbf{c m})\end{array}$ & $\begin{array}{c}\text { Plant } \\
\text { spread at } \\
\text { harvest }(c \\
\text { m) }\end{array}$ & $\begin{array}{c}\text { Number } \\
\text { of } \\
\text { branche } \\
\text { s at } \\
\text { harvest }\end{array}$ & $\begin{array}{c}\text { Leaf area } \\
\text { at } \\
\text { harvest } \\
(\text { sq. cm } \\
\left.\text { plant }^{-1}\right)\end{array}$ & $\begin{array}{c}\text { Dry weight } \\
\text { of leaf } \\
\left(\text { g plant }^{-1}\right)\end{array}$ & $\begin{array}{l}\text { Number } \\
\text { of } \\
\text { flowers } \\
\text { plant }^{-1}\end{array}$ & $\begin{array}{c}\text { Fresh } \\
\text { weight of } \\
\text { calyces (g } \\
\left.\text { plant }^{-1}\right)\end{array}$ & $\begin{array}{c}\text { Dry } \\
\text { weight of } \\
\text { calyces }(\mathrm{g} \\
\left.\text { plant }^{-1}\right)\end{array}$ & $\begin{array}{c}\text { Fresh } \\
\text { calyces } \\
\text { yield } \\
\left(\mathbf{t ~ h a}^{-1}\right)\end{array}$ & $\begin{array}{c}\text { Dry } \\
\text { calyces } \\
\text { yield } \\
\left(\mathrm{t} \mathrm{ha}^{-1}\right)\end{array}$ & $\begin{array}{c}\text { Seed } \\
\text { yield } \\
(\mathbf{g} \text { plant } \\
\mathbf{1} \text { ) }\end{array}$ & $\begin{array}{c}\text { Seed } \\
\text { yield } \\
\left(\mathbf{q} \mathbf{h a}^{-1}\right)\end{array}$ & $\begin{array}{c}\text { Anthocya } \\
\text { nin } \\
\text { content } \\
(\mathbf{m g} 100 \\
\left.\mathrm{g}^{-1}\right)\end{array}$ & $\begin{array}{c}\text { Anthocya } \\
\text { nin yield } \\
\left(\mathrm{kg} \mathrm{ha}^{-1}\right)\end{array}$ \\
\hline $\mathrm{T}_{3-}$ Sole Roselle & 135.7 & 72.0 & 14.8 & 5185 & 27.10 & 72 & 325.33 & 28.62 & 6.75 & 0.60 & 26.93 & 8.12 & 35.10 & 2.34 \\
\hline $\mathrm{T}_{9-}$ Pigeon pea + Roselle & 144.9 & 68.5 & 13.8 & 3361 & 14.80 & 61 & 236.27 & 20.13 & 4.06 & 0.41 & 19.20 & 4.38 & 30.01 & 1.24 \\
\hline $\mathrm{T}_{13-}$ Castor + Roselle & 147.6 & 58.5 & 9.8 & 2961 & 11.85 & 39 & 155.20 & 15.13 & 3.39 & 0.36 & 17.13 & 3.38 & 26.48 & 0.89 \\
\hline S.Em \pm & 1.3 & 2.5 & 0.6 & 438 & 2.95 & 6 & 30.12 & 2.17 & 0.64 & 0.05 & 1.94 & 0.85 & 0.84 & 0.12 \\
\hline C.D. at $5 \%$ & $5.0 *$ & $9.9 *$ & $2.2 *$ & $1721 *$ & $11.58 *$ & $24 *$ & $118.25 *$ & $8.50 *$ & $2.51 *$ & $0.19 *$ & $7.60 *$ & $3.34 *$ & $3.29^{*}$ & $0.80 *$ \\
\hline
\end{tabular}

Table.5 Effect of intercropping systems on growth, yield and quality parameters of holy basil

\begin{tabular}{|c|c|c|c|c|c|c|c|c|c|c|c|}
\hline Treatments & $\begin{array}{c}\text { Plant } \\
\text { height } \\
(\mathrm{cm}) A t \\
\text { harvest }\end{array}$ & $\begin{array}{c}\text { Plant } \\
\text { spread } \\
\text { (cm)At } \\
\text { harvest }\end{array}$ & $\begin{array}{c}\text { Number of } \\
\text { primary } \\
\text { branches per } \\
\text { plant At harvest }\end{array}$ & $\begin{array}{l}\text { Leaf area } \\
\text { at harvest } \\
(\text { sq. cm } \\
\left.\text { plant }^{-1}\right)\end{array}$ & $\begin{array}{l}\text { Fresh } \\
\text { weight (g } \\
\left.\text { plant }^{-1}\right)\end{array}$ & $\begin{array}{c}\text { Dry weight } \\
\left(\text { g plant }^{-1}\right)\end{array}$ & $\begin{array}{c}\text { Shade dried } \\
\text { herb yield (t } \\
\left.\qquad \mathbf{h a}^{-1}\right)\end{array}$ & $\begin{array}{l}\text { Essential oil } \\
\text { content }(\%)\end{array}$ & $\begin{array}{c}\text { Oil yield (kg } \\
\left.\text { ha }^{-1}\right)\end{array}$ & Eugenol (\%) & $\begin{array}{l}\text { Eugenol } \\
\text { yield (kg ha: } \\
\text { 1) }\end{array}$ \\
\hline $\mathrm{T}_{4-}$ Sole Holy basil & 57.7 & 54.3 & 11.0 & 1907 & 98.33 & 15.44 & 4.33 & 0.26 & 11.34 & 68.95 & 7.82 \\
\hline $\mathrm{T}_{10-}$ Pigeon pea + Holy basil & 60.0 & 51.0 & 8.2 & 1545 & 57.61 & 7.72 & 1.75 & 0.22 & 3.79 & 65.81 & 2.49 \\
\hline $\mathrm{T}_{14-}$ Castor + Holy basil & 63.7 & 25.0 & 6.6 & 688 & 26.64 & 3.98 & 0.81 & 0.22 & 1.75 & 66.63 & 1.17 \\
\hline S.Em+ & 1.1 & 4.4 & 0.7 & 173 & 10.29 & 1.34 & 0.36 & 0.01 & 0.86 & NA & 0.58 \\
\hline C.D. at $5 \%$ & $4.4 *$ & $17.6^{*}$ & $2.8^{*}$ & $681^{*}$ & $40.42 *$ & $5.27 *$ & $1.42 *$ & $0.03 *$ & $3.38 *$ & NA & $2.26 *$ \\
\hline
\end{tabular}


Table.6 Assessment of yield advantage and economic analysis of different intercropping systems

\begin{tabular}{|c|c|c|c|c|c|c|c|c|}
\hline Treatments & LER & ATER & $\begin{array}{c}\text { Pigeon pea } \\
\text { equivalent yield } \\
\left(\mathrm{q} \mathrm{ha}^{-1}\right)\end{array}$ & $\begin{array}{c}\text { Castor equivalent } \\
\text { yield } \\
\left(\mathbf{q ~ h a} \mathbf{~ h a}^{-1}\right)\end{array}$ & $\begin{array}{c}\text { Gross } \\
\text { return } \\
\left(₹ \mathbf{h a}^{-1}\right)\end{array}$ & \begin{tabular}{|c|}
$\begin{array}{c}\text { Cost of } \\
\text { cultivation } \\
\left(₹ \text { ha }^{-1}\right)\end{array}$ \\
\end{tabular} & $\begin{array}{c}\text { Net return } \\
\left(₹ \text { ha }^{-1}\right)\end{array}$ & B:C ratio \\
\hline $\mathrm{T}_{1}$-Garden rue & - & - & - & - & 0.0 & 16171.0 & -16171.0 & -1.00 \\
\hline $\mathrm{T}_{2}$-Ashwagandha & 1.00 & 1.00 & 0.75 & 0.85 & 2991.0 & 11880.0 & -8889.0 & -0.75 \\
\hline $\mathrm{T}_{3}$-Roselle & 1.00 & 1.00 & 6.03 & 12.70 & 44300.0 & 21245.0 & 23055.0 & 1.09 \\
\hline $\mathrm{T}_{4}$-Holy basil & 1.00 & 1.00 & 5.41 & 6.18 & 21650.0 & 23596.0 & -1946.0 & -0.08 \\
\hline $\mathrm{T}_{5}$-Pigeon pea & 1.00 & 1.00 & 23.10 & 26.40 & 92400.0 & 19572.0 & 72828.0 & 3.72 \\
\hline $\mathrm{T}_{6}$-Castor & 1.00 & 1.00 & 18.02 & 20.59 & 72065.0 & 18880.0 & 53185.0 & 2.82 \\
\hline $\mathrm{T}_{7}$-Pigeon pea + Garden rue & 0.86 & 0.86 & 19.75 & 22.57 & 79000.0 & 22687.0 & 56313.0 & 2.48 \\
\hline $\mathrm{T}_{8^{-}}$Pigeon pea + Ashwagandha & 1.18 & 1.10 & 16.57 & 18.94 & 66269.0 & 22192.0 & 44077.0 & 1.99 \\
\hline $\mathrm{T}_{9}$-Pigeon pea + Roselle & 1.41 & 1.35 & 25.08 & 28.66 & 100430.0 & 24418.0 & 76012.0 & 3.11 \\
\hline $\mathrm{T}_{10^{-}}$Pigeon pea + Holy basil & 1.25 & 1.09 & 21.25 & 24.29 & 84990.0 & 23687.0 & 61303.0 & 2.59 \\
\hline $\mathrm{T}_{11}$ - Castor + Garden rue & 0.92 & 0.92 & 16.57 & 18.94 & 66290.0 & 21995.0 & 44295.0 & 2.01 \\
\hline $\mathrm{T}_{12}$-Castor + Ashwagandha & 1.20 & 1.18 & 16.00 & 18.28 & 55892.0 & 21600.0 & 34292.0 & 1.59 \\
\hline $\mathrm{T}_{13}$-Castor + Roselle & 1.29 & 1.29 & 19.49 & 22.27 & 85920.0 & 22976.0 & 62944.0 & 2.74 \\
\hline $\mathrm{T}_{14}$ - Castor + Holy basil & 1.11 & 1.05 & 17.67 & 20.20 & 70690.0 & 22995.0 & 47695.0 & 2.07 \\
\hline S.Em \pm & 0.07 & 0.06 & 1.02 & 1.23 & & & & \\
\hline C.D. at $5 \%$ & $0.21 *$ & $0.19 *$ & $2.97 *$ & $3.60 *$ & & & & \\
\hline
\end{tabular}

Table.7 Market price of various crops prevailed respective during cropping seasons (2011-12)

\begin{tabular}{|c|c|c|c|c|c|}
\hline Crop & Yield A & Yield B & Price $(\mathrm{A})$ & Price (B) & Source \\
\hline Garden rue & Dried herb & & $₹ 25000.00 \mathrm{t}^{1}$ & & \multirow{2}{*}{ Himalaya Drugs, Bangalore } \\
\hline Ashwagandha & Dried root & & $₹ 100.00 \mathrm{~kg}^{-1}$ & & \\
\hline Roselle & Dried calyces & Seed & $₹ 40000.00 \mathrm{t}^{-1}$ & $₹ 2500.00 \mathrm{q}^{-1}$ & UAS, Bangalore \\
\hline Holy basil & Shade dried herb & & $₹ 5000.00 \mathrm{t}^{-1}$ & & Himalaya Drugs, Bangalore \\
\hline Pigeon pea & Seed yield & & $₹ 4000.00 \mathrm{q}^{-1}$ & & \multirow{2}{*}{ APMC, Karnataka } \\
\hline Castor & Seed yield & & $₹ 3500.00 \mathrm{q}^{-1}$ & & \\
\hline
\end{tabular}


Intercropping did not have any effect on number of primary roots, length of roots and thickness of roots. But, the dry weight of root per plant was reduced significantly by intercropping due to reduced availability of light which in turn reduced photosynthesis, and accumulation of photosynthates. As the sole ashwagandha recorded higher dry weight of roots per plant $(0.57 \mathrm{~g})$, it recorded highest dry weight of roots per hectare $(29.91 \mathrm{~kg})$. The severe reduction in root yield under intercropping may also be due to reduction in plant population by 22 per cent as compared to sole crop. In a similar study, dry root yield was reduced, similarly when ashwagandha was intercropped with pigeon pea in various row proportions (Koppalkar, 2007). The yield of ashwagandha was very low as compared to normal yield of 300-500 kg ha ${ }^{-1}$; (Farooqi and Sreeramu, 2004) and the roots obtained from all treatments were of B grade (Table 3).

\section{Effect of intercropping systems on growth, yield and quality of roselle}

Maximum plant height was recorded in roselle intercropped with castor $(147.60 \mathrm{~cm})$, followed by pigeon pea, which was significantly higher than sole crop (135.73 $\mathrm{cm})$ due to shade effect. Branching is an important growth parameter in roselle as the flowers are produced in leaf axiles. Number branches lead to more yield. Due to lack of intercomponent competition, more number of branches was recorded in sole crop (14.8 at harvest), while, it was significantly low in intercropping with castor (9.8 at harvest). Sole roselle recorded significantly highest leaf area, flowers per plant and dry weight of leaves at harvest (5185 sq. $\mathrm{cm} \mathrm{plant}^{-1}, 72$ and $27.10 \mathrm{~g} \mathrm{plant}{ }^{-1}$, respectively), which was followed by pigeon pea intercropping (3361 sq. cm plant ${ }^{-1}, 61$ and $14.80 \mathrm{~g}$ plant $^{-1}$, respectively) and least in castor (2961 sq. cm plant $^{-1}, 39$ and $11.85 \mathrm{~g} \mathrm{plant}^{-1}$, respectively) intercropping. Sole crop of roselle recorded maximum fresh and dry weights of calyces (325.33 and $28.62 \mathrm{~g}$ ) and seed yield per plant $(26.93 \mathrm{~g})$, followed by pigeon pea + roselle intercropping system (Table 4). The anthocyanin content and its yield were also high in sole crop of roselle $\left(35.10 \mathrm{mg} 100 \mathrm{~g}^{-1}\right.$ and $2.34 \mathrm{~kg} \mathrm{ha}^{-1}$, respectively). In a similar study, Fadl and Gebauer (2004) reported, decrease in growth and yield of roselle when grown under Acasia senegal, a tree species. Basavaraju (2010) also reported reduced active ingredients in kalmegh due to its intercropping under coconut.

\section{Effect of intercropping systems on growth, yield and quality of holy basil}

The plant height increased under castor as a result of shade. The holy basil plants were lean and lanky in growth, recording maximum plant height $(63.7 \mathrm{~cm}$ at harvest) (Table 5). But, at the same time, they recorded lowest number of branches (6.6 at harvest), and lower values for other growth parameters (688 sq. $\mathrm{cm} \mathrm{plant}^{-1}$ leaf area at harvest) and yield as well $\left(0.81 \mathrm{t} \mathrm{ha}^{-1}\right)$. The sole crop of holy basil recorded the highest number of branches (11.00), which also recorded higher plant spread $(54.3 \mathrm{~cm})$, maximum leaf area (1907 sq. cm plant ${ }^{-1}$ ) and fresh and dry herb yield per plant (98.33 and $15.44 \mathrm{~g}$, respectively). The results tally with the finding of Channabasappa et al., (2007), who reported reduction in growth when basil was grown under areca nut. Basavaraju (2010) in a study on intercropping of basil in coconut garden recorded lower yield of holy basil due to reduced branching, number of leaves per plant and dry matter per plant.

It also yielded highest shade dried herb per hectare (4.33 ton). The yield of holy basil in pigeon pea + holy basil intercropping (1.75 ton $\mathrm{ha}^{-1}$ ) was at par with castor + holy basil (0.81 ton $\mathrm{ha}^{-1}$ ) intercropping system as the growth of holy basil under castor was reduced 
to a greater extent owing to its shade (Table $5)$. The oil content was also highest in sole crop of holy basil $(0.26 \%)$ as the crop received maximum sun light. While, the oil content did not differ in holy basil grown with pigeon pea $(0.22 \%)$ and castor $(0.22 \%)$ and the same trend was recorded in case of oil and eugenol yield (11.73 and $7.82 \mathrm{~kg} \mathrm{ha}^{-1}$, respectively).

$\begin{array}{lll}\text { Assessment of yield advantage and } & \text { and } \\ \text { economic } & \text { analysis } & \text { of } \text { different } \\ \text { intercropping system } & & \end{array}$

Land equivalent ratio is a measure of efficiency of a particular cropping system. It is evident from the data intercropping systems are more efficient than the sole crops. The pigeon pea + roselle intercropping system recorded significantly highest LER (1.41). Garden rue failed completely, recording LER < 1. After pigeon pea + roselle, the next best system was castor + roselle, with no much reduction in castor yield due to roselle showing a LER of 1.29 (Table 6). ATER followed almost the similar trend as that of LER. In a similar study, Maitra et al., (2000) recorded higher land equivalent ratio from finger millet + pigeon pea as there was less competition between the component crops as compared to pigeon pea with ground nut. In the current study, the ATER of intercropping systems involving holy basil was lesser than that of roselle as the holy basil experienced shade to a greater extent especially under castor.

The pigeon pea + roselle system recorded highest gross and net returns due to combined yield of component crops and with higher market price of both crops which recorded $25.11 \mathrm{q}$ of pigeon pea equivalent yield $\mathrm{ha}^{-1}$. Even though, the cost of cultivation for this system was high (₹ $24418.0 \mathrm{ha}^{-1}$ ) due to the high labour input required to harvest the calyces of roselle, the system recorded highest net returns. Among the castor intercropping systems, the one with roselle recorded highest collective yield (24.55 q castor equivalent yield ha $\left.{ }^{-1}\right)$ than that of sole castor (20.59 $\mathrm{q} \mathrm{ha}^{-}$ $\left.{ }^{1}\right)$. In roselle we can take calyces and after maturity of capsule seeds are obtained that is both calyces and seeds are economic parts. The selling price of roselle calyces and seed was ₹ 40 and 25 respectively. Hence, the systems with roselle performed better even though the yield of main crop was reduced due to roselle as an intercrop. The other cropping systems were poor performers as either they recorded less yield as in case of pigeon pea + ashwagandha (pigeon pea equivalent yield of $16.57 \mathrm{q} \mathrm{ha}^{-1}$ ) and castor + ashwagandha (pigeon pea equivalent yield of $13.97 \mathrm{q} \mathrm{ha}^{-1}$ ), or the produce fetches less market price (Holy basil ₹ $5.00 \mathrm{~kg}^{-1}$ of dried herb). Since, the cost of cultivation was less for sole crops ( $₹ 19572.00 \mathrm{ha}^{-1}$ for pigeon pea and ₹ $18880.0 \mathrm{ha}^{-1}$ for castor), the highest benefit cost ratios were obtained in sole crops of pigeon pea (3.72) and castor (2.82) (Table $6)$.

The inter-space available in case of pigeon pea and castor can be successfully utilized for cultivation of medicinal crops under dry land conditions in alfisols of Eastern dry zone of Karnataka. Whenever pigeon pea and castor are sown in early to mid Kharif and good rains are expected, roselle can be grown as an intercrop by sowing a row in between two rows of pigeon pea and castor without reducing their population.

\section{References}

Basavaraju, T.B., 2010. Identification and development of integrated nutrient management for promising medicinal and aromatic plants as intercrops in coconut (Cocos nucifera 1.), Ph.D thesis submitted to Department of Agronomy, University of Agricultural Sciences, 
GKVK, Bangalore.

Channabasappa, K.S., Praveenakumar, and Madiwalar, S.L., 2007. Influence of arecanut on economic yield and quality parameters of medicinal Plants. Karnataka J. Agric. Sci., 20 (4): 880882.

Fadl, K.E.M., and Gebauer, J., 2004. Crop Performance and Yield of Groundnut, Sesame and Roselle in an Agroforesty Cropping System with Acacia senegal in North Kordofan (Sudan). Journal of Agriculture and Rural Development in the Tropics and Subtropics, 105 (2):149-154.

Gupta, I.N., and Rathore, S.S., 1993. Intercropping of castor (Ricinus communis L.) under dry land condition in Rajastan. Indian J. Agron., 38(2):182-186.

Hiebsch, C.K., and Macollam, R.E., 1980. Area time equivalency ratio. A method for evaluating the productivity of intercrops. Agron. J., 79: 15-22.

Kawano, K.H., Gonzalez and Lucena, M., 1974. Intra-specific competition, competition with weeds and spacing response in rice. Crop Sci. 14: 841-845.

Koppalkar, B.G., 2007. Studies on planting geometry and nutrient management in companion cropping of pigeonpea (Cajanus cajan (L.) Millsp.) And ashwagandha (Withania somnifera Dunal). Ph.D. Thesis, University of Agricultural Sciences, Dharwad.

Madhavi lata A., Srinivasa raju M. Josep B., Siva Shankar A. and Chandrasekhar rao P., 2012. Performance of medicinal herbs in tree based cropping system under dry land conditions, $J$. Pharmacognosy, 3(2): 92-95.

Maitra, S., Ghosh, D.C., Sounda, G., Jana, P.K. and Roy, D.K. 2000. Productivity, competition and economics of intercropping legumes in finger millet at different fertility levels. Indian $J$. Agril. Sci., 70: 824-828.

Prakasa Rao, E.V.S., Ganesha Rao, R.S. and Ramesh, S., 1996. Changes in content and composition of some essential oils due to possible deficiencies of phosphorous and potassium in red soil region of Bangalore. Pafai J., 18: 2527.

Prasad, S.N., and Verma, B., 1986. Effect of inter cropping castor with greengram, blackgram, sesame and sorghum on yield and net return. Indian J. Agron., 31(1):21-25.

Sankaran, S., and Rangaswamy, A., 1990. Farming Systems Research - In Agronomic Research towards Sustainable Agriculture (edited by Singh K. N. and Singh, R. P.), Indian Society of Agronomy, Division of Agronomy, IARI, New Delhi, pp. 6980.

Ved, D.K., and Goraya, G.S., 2008. Demand and supply of medicinal plants in India. Foundation for Revitalization of local health traditions (FRLHT), Bangalore, India. p 216.

Willey, R.W., 1979. Intercropping: its importance and research needs: Part I. Competition and yield advantages. Field Crop Abst, 32: 1103.

\section{How to cite this article:}

Pushpa, T.N., K. Umesha, M. Vasundhara, B.K. Ramachandrappa, B.S. Sreeramu and Srikantaprasad, D. 2017. Intercropping of Roselle with Red Gram and Nipped Castor is Beneficial to Dry Land Farmer. Int.J.Curr.Microbiol.App.Sci. 6(9): 2179-2188. doi: https://doi.org/10.20546/ijcmas.2017.609.268 